\title{
Some Economic Aggregates for Canadian Forest Industries
}

\author{
by
}

James Dobie R.P.F. ${ }^{1}$

\begin{abstract}
This article presents economic aggregates for the forest industries in Canada with some discussion on Gross Domestic Product, regional impacts, external trade, employment and multipliers.

The goods-producing sector in recent years has comprised $40 \%$ of the economy, with manufacturing being $50 \%$ of goods-producing or $20 \%$ of the total economy. Forest-based industries in aggregate are diminishing over time in their contribution to the economy, dropping from $5.1 \%$ of total GDP in the early 1960 s to $3.5 \%$ in the early $1980 \mathrm{~s}$. Wood industries and paper and allied industries together constituted $14 \%$ of manufacturing GDP in 1986, down from 21\% in 1961.

Forest products exports, with a surplus of $\$ 13.5$ billion in 1986, contribute significantly to Canada's merchandise trade balance. Employee productivity has been growing recently at $5.33 \%$ per annum. If there are no increases in volume of timber harvested, increasing productivity will result in employment reductions.
\end{abstract}

Keywords: Forest Economics, Gross Domestic Product, Productivity, and Multipliers.

\section{Résumé}

Cet article présente les indicateurs économiques de l'industrie forestière du Canada, tout en élaborant sur le produit intérieur brut, les impacts régionaux, le commerce extérieur, l'emploi et les multiplicateurs.

Le secteur de l'industrie des biens a concouru au cours des dernières années à $40 \%$ de l'économie, le secteur manufacturier comptant pour $50 \%$ de l'industrie des biens ou $20 \%$ de l'économie totale. L'ensemble des industries du secteur forestier a vu diminuer la part de sa contribution à l'économie, passant de $5.1 \%$ du P.I.B. au début des années 1960 , à $3.5 \%$ au début des années 1980 . L'industrie du bois et du papier ainsi que les industries connexes constituaient $14 \%$ du P.I.B. du secteur manufacturier en 1986, une diminution de 7\% par rapport à 1961 .

Les exportations de produits forestiers contribuent d'une manière significative à la balance des echanges commerciaux du Canada par un surplus de $\$ 13.5$ milliards en 1986. La produciivité des employés s'est accrue récemment au rythme de 5.3\% par an. S'il n'y a pas d'augmentation du volume de bois récolté, l'accroissement de la productivité provoquera une réduction de l'emploi.

Mots clés: Economie forestière, Produit intérieur brut, Productivité, Multiplicateurs

\section{Introduction}

Economic aggregates are useful for broad overviews of an industry, and can provide effective background material for arguing the relative merits of forestry for funding or other policy consideration. Also, as the economy evolves over time, the relative importance of industries may change. For the sake of credibility, keeping abreast of any such changes is important. On the basis of limited research it appears that nothing has been published in the Chronicle for several years specific to the aggregate contribution of the forest industries

Forest Economist, Statistics Canada, Pacific Region, 340 Sinclair Centre, 757 West Hastings St., Vancouver, B.C. V6C 3C9 to the Canadian economy. On the premise that periodic refreshers on the aggregate economies of the forest industry in our society are useful to foresters, the purpose of this article is to provide such a refresher.

In this paper, the economic aggregates presented use Gross Domestic Product (GDP) at factor cost, which, in my opinion, is the correct measure to apply when describing the contribution of an industry to an economy.

Following a description of GDP there is a brief outline of the sectors of the Canadian economy, which precedes a more detailed appraisal of the forest industries from the perspectives of GDP, regional impacts, trade, employment and multipliers. 


\section{GDP at Factor Cost}

In 1986 Statistics Canada switched from Gross National Product (GNP) to Gross Domestic Product (GDP) as the principal measure of the magnitude of Canadian economic activity. GDP estimates economic activity within geographic limits regardless of nationality of ownership of the factors of production, whereas GNP estimates activity on the basis of nationality. Thus, interest and dividends accruing to nonresidents from investments in Canada are included in Canadian GDP but not GNP. Similarly, interest and dividends accruing to Canadian residents from foreign investments are included in GNP but not GDP. As the outflows are normally much greater than the inflows, GDP is normally greater than GNP. GDP is regarded therefore as a better indicator of economic activity within the country than GNP. Furthermore, GDP can be linked directly to domestic employment to ascertain trends in productivity.

Two measures of GDP are: (1) GDP at factor cost, and (2) GDP at market prices. GDP at factor cost is equivalent to true value-added, and is the difference between the value of gross output of an industry and the cost of intermediate inputs such as materials and supplies, fuel and electricity, purchased service inputs, and the residual of indirect taxes less subsidies. GDP at market prices is equivalent to GDP at factor cost plus the residual of indirect taxes less subsidies. As direct taxes are normally greater than subsidies for most industries, GDP at market prices is normally greater than GDP at factor cost.

GDP at factor cost is therefore an estimate of the unduplicated returns to the factors of production which are labour, capital and entrepreneurship. GDP at factor cost represents salaries and wages, capital cost allowances, taxes and profits, and is the best measure of the contribution of an industry to any particular economy, at the regional or national level. Any reference to GDP in the ensuing presentation refers strictly to GDP at factor cost.

\section{Structure of the Economy}

The Canadian economy is often divided into its two major components, the goods-producing sector and the serviceproducing sector. In 1986, the goods-producing sector accounted for almost $40 \%$ of the total Canadian GDP, with the service sector accounting for the remainder (Table 1$)^{2}$. Over the 25 years from 1961 to 1986 , the goods-producing sector has gradually diminished in relative importance to the service sector (Table 2).

In the period from 1961 to 1965 the ratio of goods to services was roughly $45: 55$, whereas in the $1982-86$ period the ratio had changed to roughly $39: 61$. The cause of this sectoral change in relative importance is the growth rates shown in Table 2. Goods-producing industries on aggregate grew at a slower rate than the economy as a whole, but the service sector grew faster.

Manufacturing in the 1961-65 period accounted for about $21 \%$ of the total GDP in the economy and declined to $19 \%$ in the $1982-86$ period. However in 1986 this percentage was the same (20) as in 1961, reflecting the fact that the growth rates for total and manufacturing GDPs were equal. With the goods-

Table 1. Canadian GDP 1986

$\$ 1981$ Millions

Good-Producing:

Agriculture

Fishing \& trapping

Logging \& forestry

Mines, quarries, oil wells

Manufacturing

Construction

Utilities

Non-business sector goods

Service-Producing

Transportation \& storage

Communications

Wholesale trade

Retail trade

Finance, insurance, real estate

Community, business, personal services

Government service industries

Total Economy

Source: Statistics Canada Cat. No. 15-001 Monthly.

Table 2. Contribution to Canadian GDP and average real annual growth rates 1961 to 1986 for selected industries.

\begin{tabular}{lccc}
\hline Industries & \multicolumn{2}{c}{$\begin{array}{c}\text { Percent of total GDP } \\
\text { 1961-65 }\end{array}$} & $\begin{array}{c}\text { 1982-86 } \\
\text { per anth rate }\end{array}$ \\
\hline Goods-Producing & 45.1 & 39.4 & (\%) \\
\hline Service-Producing & 54.9 & 60.6 & 3.91 \\
Manufacturing & 20.7 & 18.9 & 4.63 \\
Logging \& Forestry & 1.1 & 0.7 & 2.15 \\
Wood & 1.1 & 1.0 & 4.37 \\
Paper \& Allied & 2.9 & 1.8 & 2.11 \\
Total GDP & & & 4.33 \\
\hline
\end{tabular}

1. Growth rates represent average annual percentage constant dollar increases from 1961 to 1986 .

Source: Derived from Statistics Canada Cats. No. 15-001 Monthly. 15-512 Occasional.

producing sector diminishing as a percentage of total GDP from 1963 to 1986 , and manufacturing remaining constant, manufacturing therefore increased as a proportion of goodsproducing GDP, from 44\% in 1961 to $50 \%$ in 1986 .

In the period from 1961 to 1965 , paper and allied industries formed the most important group in manufacturing in Canada, constituting $14.09 \%$ of manufacturing GDP (Table 3). In the 1971-75 period it was still the leading group but had diminished to $11.32 \%$ of manufacturing GDP. In the 1981-85 period, paper and allied industries was third in importance after the transportation industries and food industries, and had slipped to $9.42 \%$ of manufacturing GDP. In those same periods the wood industries group was 9th or 10th ranked with between 4.41 to 5.23 percent of manufacturing GDP.

\section{Forest-Based Industries}

\section{i) National Impact}

The contribution of the forest-based industries ${ }^{3}$ of logging and forestry, wood industries, and paper and allied industries 
Table 3. Leading manufacturing industries of Canada.

\begin{tabular}{|c|c|c|c|}
\hline \multirow[b]{3}{*}{ Industry } & \multicolumn{3}{|c|}{ Period } \\
\hline & $1961-65$ & $1971-75$ & $1981-85$ \\
\hline & \multicolumn{3}{|c|}{ Percentage of manufacturing GDP } \\
\hline Paper and Allied & 14.09 & 11.32 & 9.42 \\
\hline Food & 13.71 & 10.75 & 10.38 \\
\hline Primary Metal & 11.35 & 10.29 & 7.91 \\
\hline Metal Fabrication & 8.88 & 8.99 & 7.34 \\
\hline \multicolumn{4}{|l|}{ Transportation } \\
\hline Equipment & 6.27 & 11.13 & 11.77 \\
\hline \multicolumn{4}{|l|}{ Printing, Publishing \& } \\
\hline Allied & 5.98 & 4.62 & 5.55 \\
\hline \multicolumn{4}{|l|}{ Chemicals \& } \\
\hline Chemical Products & 5.67 & 5.86 & 7.34 \\
\hline Electrical \& Electronics & 5.66 & 5.77 & 8.70 \\
\hline Wood & 5.23 & 4.41 & 5.08 \\
\hline Machinery & 4.50 & 4.74 & 4.43 \\
\hline All Other & 18.66 & 22.12 & 22.08 \\
\hline
\end{tabular}

Source: Statistics Canada Cats. No. 15-001 Monthly, 15-512 Occasional.

dropped in aggregate from $5.1 \%$ of total GDP in the 1961-1965 period to $3.5 \%$ in the $1982-1986$ period (Table 2 ), with the largest decrease occurring in paper and allied industries, followed by logging and forestry. Wood industries maintained its contribution of $5 \%$ to total manufacturing GDP from 1961 to 1986 , but paper and allied dropped from $16 \%$ in 1961 to $9 \%$ in 1986 . The two together were $14 \%$ of national manufacturing GDP in 1986 versus 21\% in 1961 .

\section{ii) Regional Impacts}

The contribution of the forest industries to national and regional economies varies by region across Canada. British Columbia generally contributes about $50 \%$ to the value of shipments in logging followed by Quebec with about $18 \%$, Ontario with 17, and the rest with around $15 \%$.

In solid wood products manufacture, British Columbia also dominates with about $47 \%$ of total Canadian shipments in 1986 , followed by Quebec (22\%) and Ontario (19\%) (Table 4).

Quebec and Ontario dominate in paper and allied products manufacturing shipments with almost one-third each of the Canadian total in 1986. These are followed by B.C. with $20 \%$, and the rest of the provinces with $15 \%$ in total.

For all manufactured forest products the shares of 1986 value of shipments for B.C. (30\%), Quebec (29\%) and Ontario $(27 \%)$ were very close to each other. With regard to total regional manufacturing, forest products manufacturing accounted for about $46 \%$ of the B.C. total, $15 \%$ of the Quebec

Table 4. Regional origin of manufactured forest products shipments in Canada - 1986.

\begin{tabular}{lccr}
\hline Region & $\begin{array}{c}\text { Wood } \\
\text { industries } \\
\text { products }\end{array}$ & $\begin{array}{c}\text { Paper and } \\
\text { allied } \\
\text { products }\end{array}$ & \multicolumn{1}{c}{ Total } \\
\hline Quebec & Percentage of Canadian total \\
\cline { 2 - 4 } Ontario & 22.28 & 32.99 & 28.96 \\
British Columbia & 19.37 & 32.21 & 27.38 \\
Rest of Canada & 46.57 & 20.04 & 30.02 \\
Total & 11.78 & 14.76 & 13.64 \\
\hline
\end{tabular}

Source: Statistics Canada Cats. No. 31-001 Monthly.
Table 5. Forest products' share of regional manufacturing shipments in Canada - 1986.

\begin{tabular}{lccr}
\hline Region & $\begin{array}{c}\text { Total } \\
\text { shipments }\end{array}$ & $\begin{array}{c}\text { Forest } \\
\text { products } \\
\text { shipments }\end{array}$ & $\begin{array}{c}\text { Forest } \\
\text { products } \\
\% \text { total }\end{array}$ \\
\cline { 2 - 4 } & \multicolumn{2}{c}{ Percentage of dollars (1986) } \\
\hline Quebec & 60603 & 9106 & 15.0 \\
Ontario & 133249 & 8608 & 6.5 \\
British Columbia & 20639 & 9439 & 45.7 \\
Rest of Canada & 35370 & 4288 & 12.1 \\
Total & 249861 & 31441 & 12.6 \\
\hline
\end{tabular}

Source: Statistics Canada Cats. No. 31-001 Monthly.

total and $6.5 \%$ of the Ontario total (Table 5). For Canada as a whole forest products manufacturing accounted for $12.6 \%$ of total manufacturing shipments in 1986.

\section{iii) GDP and Gross Output}

As stated previously, GDP at factor cost is the value of gross output minus the cost of intermediate inputs. In estimating gross output for an industry the "total activity" concept is used for the establishments in that industry. For example, if an establishment classified to manufacturing also transports and sells its own goods at the wholesale level, these secondary activities will be included in the establishment's output and therefore in the manufacturing industry.

For each of the major forest-based industries in Canada, GDP as a percentage of their gross output during the past 25 years has not varied more than 1 or 2 percentage points from the average of $35 \%$. Thus if estimates of GDP are available, gross output can be estimated. This fact is useful because GDP estimates are normally published several years in advance of gross output estimates, and gross output for some industries may vary substantially from value of shipments. ${ }^{4}$

GDP in 1986 for logging and forestry, wood industries and paper and allied industries was \$2 451 million, \$3 665 million and $\$ 6552$ million respectively in $\$ 1981$. Therefore using GDP as $35 \%$ of gross output, estimated gross output in 1986 for the above industries are $\$ 7003$ million, $\$ 10471$ million, and $\$ 18720$ million in $\$ 1981$. Using industrial product price indexes available for roundwood, wood industries, and paper and allied industries, the above $\$ 1981$ figures would be increased by $9.3 \%, 18.9 \%$ and $17.3 \%$ respectively for 1986 dollar values.

\section{iv) International Trade}

The current account balance of Canada's international payments and receipts is composed of the merchandise trade balance and the non-merchandise transaction balance. The latter incorporates such charges as interest and dividends, travel, freight, and other service receipts or payments.

Traditionally Canada runs a surplus in merchandise trade and a deficit in non-merchandise transactions. The current account balance is more often negative than positive because the deficit in non-merchandise transactions is normally

${ }^{4} \mathrm{GDP}$ estimates and value of shipments are published monthly. Gross output estimates are obtained from annual census of manufactures and are published annually normally 2 years after the reference year. 
Table 6. Canadian international trade balances.

\begin{tabular}{lcccc}
\hline Year & $\begin{array}{c}\text { Merchandise } \\
\text { trade } \\
\text { balance }\end{array}$ & $\begin{array}{c}\text { Non- } \\
\text { merchandise } \\
\text { trade } \\
\text { balance }\end{array}$ & $\begin{array}{c}\text { Current } \\
\text { account } \\
\text { balance }\end{array}$ & $\begin{array}{c}\text { Lumber } \\
\text { Newsprint, } \\
\text { woodpulp } \\
\text { balance }\end{array}$ \\
\hline \multicolumn{5}{c}{ Millions of dollars } \\
\hline 1982 & 17813 & $(15148)$ & 2665 & 9948 \\
1983 & 17705 & $(16020)$ & 1685 & 10676 \\
1984 & 20237 & $(16800)$ & 3437 & 11867 \\
1985 & 16926 & $(18111)$ & $(1185)$ & 12115 \\
1986 & 10388 & $(19656)$ & $(9268)$ & 13500 \\
\hline
\end{tabular}

( ) signifies negative balances.

Source: Statistics Canada Cat. No. 67-001 Quarterly.

greater than the surplus in merchandise trade. In the 15 years from 1971 to 1986 inclusive, the current account balance was positive 5 times and negative 11. The average balance in the 16 years was - \$2 173 million. In 1986 the current account balance was - \$9268 compared with - \$1 186 in 1985, the difference being largely due to an $\$ 8$-billion-dollar increase in imports from 1985 to 1986.

The surplus normally run in merchandise trade is due in large part to forest product exports (Table 6). In the 5 years from 1982 through 1986, the trade surplus for forest products increased from $\$ 9.9$ billion to $\$ 13.5$ billion, with about $76 \%$ of this surplus resulting from trade with the United States. Forest products exports contribute more to Canada's positive merchandise trade balance than any other commodity exports.

\section{v) Employment and Productivity}

Total employment in the logging, wood, and paper and allied industries in the 10-year period from 1976 to 1985 ranged from a high of 310000 in 1979 to a low of 257000 in 1982. In 1985, the latest year for which census of manufactures data are currently available, total employment was about 268000 person-years (Table 7).

GDP per cubic metre of roundwood produced was quite variable in the 5-year period 1981-1985, but averaed about $\$ 72.50$ in constant 1981 dollars. Therefore, the three major industry groupings had an unduplicated average GDP, or true value-added, of $\$ 72.50$ in $\$ 1981$ per cubic metre of total roundwood production from 1981 to 1985 inclusive. That is, the impact of the forest industries in the 1981-1985 period was a contribution of $\$ 72.50$ (\$1981) to the Canadian GDP for every $\mathrm{m}^{3}$ of logs harvested.
Productivity calculated on the basis of constant dollar GDP per employee increased by 23\% from 1981 to 1985 (Table 7). This productivity index represents total GDP for the three major groups of logging, wood, and paper and allied industries divided by total employment.

\section{vi) Multipliers}

a) Employment

From input-output analysis the value of inputs used in the production activity for specific industries can be ascertained. By extension to employment data, estimates can be made of how much employment is created in industries supplying input to the industry in question.

Employment created in providing materials and supplies to enable production in another industry is termed indirect employment. Adding indirect employment to the direct employment for forest-based industries results in employment multipliers for direct and indirect employment (Table 8). The interpretation of the weighted average is that for every person directly employed in the forest-based industries, another 1.236 persons are employed indirectly in industries providing materials and supplies to forest industries.

Another impact of industrial activity is that labour income from the principal industry, and those engaged in supplying that industry with materials for production, generates activity in other sectors of the economy through demand for consumer goods and services. This principle is generally known as induced employment, and multipliers reflecting direct, indirect and induced are also shown in Table 8 . The interpretation of the weighted average is that for each person employed in the forest-based industries, an additional 3.293 are employed in indirect and induced as a result.

b) GDP

The rationale used for employment multipliers also applies to GDP multipliers; that is for direct and indirect GDP, and for those two plus induced (Table 8). The interpretation again is that for each dollar of GDP created directly by forestbased industries, $\$ 1.097$ in indirect GDP and \$1.354 in induced GDP were also created.

These multipliers are based on 1981 input-output analysis which was the latest available at time of writing. Current multipliers could be larger or smaller depending on whether the forest-based industries have become more or less efficient than other associated industries in the interim since 1981.

\begin{tabular}{|c|c|c|c|c|}
\hline $\begin{array}{c}\text { Total } \\
\text { employment } \\
\text { (person-years) }\end{array}$ & $\begin{array}{c}\text { Total } \\
\text { production } \\
\left({ }^{\prime} 000 \mathrm{~m}^{3}\right)\end{array}$ & $(\$ 1981)$ & (\$current) & $\begin{array}{c}\text { Index of } \$ 1981 \\
\text { GDP per } \\
\text { Employee }\end{array}$ \\
\hline
\end{tabular}

Source: Statistics Canada Cats. No.: 55-512, 25-201, 35-204, 36-204, 35-250B, 36-250B, 62-011. 
Table 8. Canadian forest industries' employment and GDP multipliers.

\begin{tabular}{lccccc}
\hline Industry & $\begin{array}{c}\text { Direct \& } \\
\text { indirect }\end{array}$ & \begin{tabular}{c} 
Employment \\
\cline { 4 - 6 }
\end{tabular} & $\begin{array}{c}\text { Direct, indirect } \\
\text { and induced }\end{array}$ & $\begin{array}{c}\text { Direct \& } \\
\text { indirect }\end{array}$ & $\begin{array}{c}\text { GDP } \\
\text { Direct, indirect } \\
\text { and induced }\end{array}$ \\
\hline Logging & 1.809 & 3.435 & 1.869 & 3.145 \\
Sawmills & 2.186 & 4.071 & 2.608 & 4.598 \\
Pulp \& Paper & 2.472 & 4.821 & 1.985 & 3.086 \\
\cline { 2 - 4 } Weighted average & 2.236 & 4.293 & 2.097 & 3.451 \\
\hline
\end{tabular}

Source: Statistics Canada unpublished data based on 1981 input-output analysis.

\section{Summary}

From the foregoing analysis the following economic aggregates emerge:

1. The current ratio of goods-producing to serviceproducing industries in Canada is about 40:60.

2. Manufacturing industries GDP is about $20 \%$ of total Canadian GDP and $50 \%$ of goods-producing GDP.

3. Forest-based industries account for around $3.5 \%$ of total national GDP.

4. Wood industries and paper and allied industries together account for about $14 \%$ of national manufacturing GDP. Paper and allied was the third most important manufacturing industry in Canada in 1986 and wood industries were 9 th.

5. For the forest-based industries individually, and therefore collectively, GDP is about $35 \%$ of gross output.
6. Forest products exports, with a trade balance of $+\$ 13.5$ billion in 1986, are the major contributor to Canada's positive merchandise trade balance.

7. Recent increases in employee productivity in forest industries in Canada averaged $5.33 \%$ per annum (1981$85)$. With no increases in production this productivity change would result in employment reductions averaging 12.2 thousand per annum up to 1990 .

8. Total GDP per $\mathrm{m}^{3}$ from 1981 to 1985 averaged $\$ 72.50$ per $\mathrm{m}^{3}$ of roundwood production in Canada in $\$ 1981$. This figure is roughly equivalent to $\$ 84.20$ in $\$ 1986$ and serves as an estimate of the direct contribution of forest industries to the Canadian economy.

9. Employment multipliers for Canadian forest industries average approximately 2.2 for direct plus indirect, and 4.3 when induced is included.

10. GDP multipliers for Canadian forest industries average 2.1 for direct and indirect, and 3.5 when induced effects are included.
Change of Address

Date Section

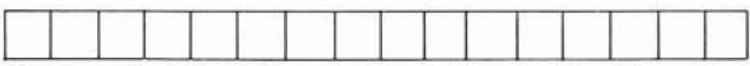

Surname first - no titles

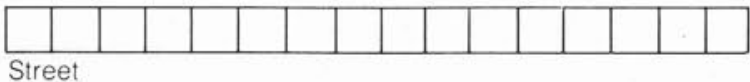

Street

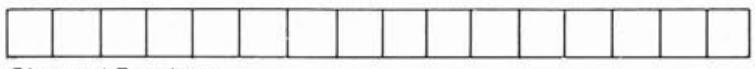

City and Province

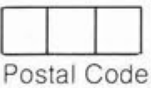

\section{Changement d'adresse}

Date Section

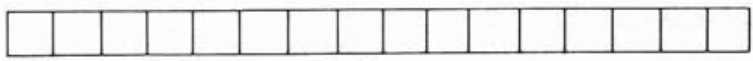

Prénom en avant - pas de titres

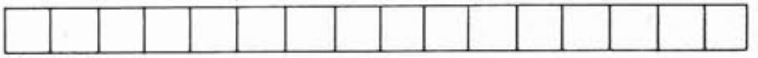

Rue

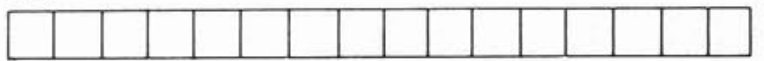

Ville et Province

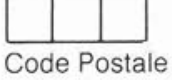

